\title{
DANIEL ZIEMBICKI
}

Uniwersytet Warszawski, Warszawa

\section{Kontrowersje interpretacyjne wypowiedzi typu Nie sądzę, że p, ja to wiem}

\section{Wstęp}

Celem niniejszego artykułu jest omówienie kontrowersji interpretacyjnych wokół wypowiedzi, których przykłady znajdują się poniżej:

(1) (a) - Mówiliście - kiwną głowa Szarlej. - Inkwizycja zatem jest zajęta wyciaganiem z owych jeńców zeznań. Chwilowo więc, sądzicie, nie będzie miała na nas czasu?

(b) - Nie sądzę. Wiem. (Narodowy Korpus Języka Polskiego (NKJP) (Pęzik 2012), źródło: „Narrenturm”, kanał: książka)

(2) (a) Naprawde wierzysz w uzaleznienia 11 latkow od hazardu, porno i narkotykow jest problemem na skale masowa?

(b) Nie wierze, tylko wiem ${ }^{1}$.

(3) Każdy wykonywat swoja pracę i starat się pokazać z jak najlepszej strony, także wydaje mi się... a właściwie nie wydaje mi się, tylko wiem o tym dobrze, że jesteśmy przygotowani $w$ stu procentach do sezonu ${ }^{2}$.

Przedmiotem analizy w przykładach (1)-(2) są przede wszystkim odpowiedzi, czyli (1b) i (2b). Sytuacja, która w (1)-(2) ma miejsce, to ,zaprzeczenie sądowi implikowanemu przez wcześniejszą wypowiedź kogoś innego i dodanie nowego sądu, prze-

1 circ, „Byłem uzależniony od wszystkiego, a moje życie to były ciągłe imprezy”, komentarz pod tekstem, w: http://www.fronda.pl/a/bylem-uzalezniony-od-wszystkiego-a-moje-zycie-to-byly-ciagle-imprezy,30822.html?page=2\&, dostęp: grudzień 2017 .

2 P. Małecki, „Zaspokoić głód kibiców”, w: http://skwk.pl/index.php/pilkanozna/11-zawodnicy/ 3333-zaspokoic-glod-kibicow.html, dostęp: grudzień 2017. 
ciwstawnego pod względem wartości logicznej” (Żabowska 2008). W wypadku (4) mamy do czynienia z korekta bądź autokorekta wypowiedzi (Ożóg 1990, Bogusławski $\left.2016^{3}\right)$. Głównym przedmiotem naszego zainteresowania w zdaniach typu (1)-(3) są różnice semantyczne pomiędzy korygowanym składnikiem (np. wydaje mi się) a nowym składnikiem, który go zastępuje (np. wiem).

\section{Hiponimia i hiperonimia}

Przydatnym narzędziem w analizie relacji powyższych składników są pojęcia hiponimii i hiperonimii. Pozwala ona podzielić analizowane wypowiedzi na kilka poniższych kategorii:

a. Rzeczowniki i czasowniki, które nie wchodzą w relację hipo-hiperonimii. Przykłady:

(4) To ciężarówka, nie pickup.

(5) To nie Marta, to Maria.

(6) On poleciat, nie pojechat.

(7) Ja tego nie skrywam, ja to rozpowszechniam!

Za pomocą tego typu wypowiedzeń można zakomunikować, że dany obiekt jest innego rodzaju albo że jest kimś/czymś innym (rzeczowniki), albo zakomunikować, że odzwierciedlane są dwa stany rzeczy, o których stwierdza się, że zamiast jednego stanu rzeczy miał miejsce inny (czasowniki). Miejsce negacji nie ma znaczenia - może być po lewej albo po prawej stronie. To, który rzeczownik lub czasownik został użyty pierwszy, też nie ma znaczenia.

Tego rodzaju wypowiedzi mogą być realizowane z odpowiednim, kontrastywnym konturem intonacyjnym, np.:

(8) - Zrobitem ci kawę.

— Nie KAWE, tylko HERBATE.

Nie wydaje się jednak, by tego rodzaju intonacja była warunkiem koniecznym niedewiacyjności takich wypowiedzi oraz by nie pełniły one wtedy funkcji wypowiedzi korygujących ${ }^{4}$.

b. Rzeczowniki i czasowniki, które wchodzą w relację hipo-hiperonimii. Przykłady:

(9) To KONDOR, nie ptak.

3 Bogusławski w swoim artukule używa terminu autopoprawka.

${ }^{4}$ Będę używał pojęcia wypowiedzi korygujące jako nazwę jednej klasy, którą mogą tworzyć razem wypowiedzi typu (1)-(4). 
(10) To nie ptak, tylko KONDOR.

(11) On się nie przemieszcza, on BIEGNIE.

W przykładach (9)-(11) hipoteza, że użycie rzeczowników lub czasowników w relacji hipo-hiperonimii przy jednoczesnym zachowaniu neutralnego konturu intonacyjnego skutkuje dewiacyjnością wypowiedzenia wydaje się już zasadna, zob. np:

(12) *To kondor, nie ptak.

(13) *To nie ptak, tylko kondor.

Argumentem na rzecz jej prawdziwości jest to, że taka wypowiedź pozbawiona byłaby koniecznego komponentu dla wypowiedzi korygującej w postaci akcentu, który może wskazywać na jakąś różnicę obydwu składników względem siebie. Nadawca może np. wyrazić za pomocą akcentu kontrastywnego sąd, że z powodu przysługujących wkazanemu obiektowi właściwości jest on wyjątkowy w swojej klasie. W przykładach (4)-(7) akcent kontrastywny nie wydaje się konieczny, ponieważ pomiędzy składnikiem korygowanym a korygującym istnieje już semantyczna, kategorialna różnica. Powyższe twierdzenia, dotyczące ukształtowania prozodycznego, muszą być jednak potwierdzone badaniami empirycznymi.

Wydaje się, że pozycja linearna rzeczowników lub czasowników w (b) również nie ma znaczenia. Wynikałoby z tego, że np. (9) i (10) są względem siebie semantycznie równoważne.

Odnotujmy jeszcze klasę (c), w której nie występują konteksty z czasownikami:

c. Rzeczowniki, które mają ten sam desygnat. Przykłady:

(14) To nie jest wilk szary. To jest canis lupus.

(15) To nie jest canis lupus. To jest wilk szary.

(16) To nie jest Gwiazda Wieczorna. To jest Gwiazda Poranna.

Klasa ta może być ujęta jako podklasa (b), ponieważ również nie ma tutaj relacji hipo-hiperonimii. Wypowiedzenie (14) można interpretować np. jako pouczenie, by używać naukowej terminologii. W (15) przeciwnie, może to być wezwanie do stosowania nazewnictwa potocznego. Wszystkie powyższe przykłady mogą też świadczyć o braku wiedzy nadawcy o tym, że obydwa rzeczowniki mają ten sam desygnat lub denotat.

Wnioski z przeprowadzenia powyższych podziałów mogą być następujące — jeśli pomiędzy składnikiem korygowanym a korygującym zachodzi relacja hipo-hiperonimii, to warunkiem koniecznym niedewiacyjności wypowiedzi korygujących jest dobór innego konturu intonacyjnego niż neutralny. Wniosek mocniejszy, który podajemy w postaci hipotezy badawczej, jest taki, że musi to być akcent kontrastywny. Jej weryfikacja wymaga odrębnych badań. 


\section{Czasowniki epistemiczne}

W dalszej części artykułu skupiamy się na wypowiedziach korygujących, w których występują czasowniki epistemiczne. Chodzi o takie pary czasowników, w których jednym jest wiedzieć, że_, a drugim inny czasownik epistemiczny, który odpowiada jakiejś postawie przekonaniowej (np. (1)-(4)). Dla lepszego przedstawienia materiału będącego przedmiotem analizy zamieszczamy przykłady zbudowane z charakterystycznych dla tego typu wypowiedzi wyrażeń (Walusiak 1999), takich jak np. nie_,; nie___; nie_tylko_; nie_lecz; nic nie_._:

(17) A mnie się nie té̇ wydaje. Ja wiem (nie sądzę, ale wiem), że różne substytuty i pastylki stosowane $w$ diecie wegańskiej sq wyjątkowym świństwem ${ }^{5}$. (NKJP, źródło: „Usenet”, kanał: Internet)

(18) Maja mnie dosyć. Moda na Leona minęła.

- Tak Ojciec myśli?

- Ja nie myślę, ja to wiem. (NKJP, źródło: „Gazeta Krakowska”, kanał: prasa dziennik)

(19) Nie sądzę - ja wiem, że jesteś debilem. Gołym okiem widać. :-P (NKJP, źródło: „Usenet -- pl.soc.polityka”, kanał: Internet)

(20) To nie „widzimisię” tylko wiedza. Ja wiem, że Ciastoń byt szefem morderców. (NKJP, źródło: „Usenet -- pl.soc.religia”, kanał: Internet)

(21) dla mnie często tragiczne jest to, że nie myśle lecz wiem... wyobraź sobie siebie, że wiesz co się wydarzy $i$ choć chcesz temu zapobiec to nie jesteś $w$ stanie (NKJP, źródło: „Usenet -- pl.sci.filozofia”, kanał: Internet)

(22) - Myślisz, że Babiniec?

- Ja nic nie myślę, Jureczku. Ja wiem. Ale ta wiedza nie czyni mnie wcale szczęśliwym. (NKJP, źródło: „Pogoda dla wszystkich”, kanał: książka)

Możliwe też są korekty dotyczące zmian w czasie lub modalności:

(23) kiedyś, nie tak dawno, myślałem (teraz nie myślę, już wiem) że aby wygrać z maszkatorem trzeba wymyślić taka, która idzie w nieskończoność [...]. (NKJP, źródło: „Usenet -- pl.hum.pisarstwo”, kanał: Internet)

(24) - Po co chcesz wiedzieć? - cicho, smutno i jakby ze skarga.

- Nie chcę wiedzieć, tylko wiem - poprawit i z lekka wzruszyt ramionami. (NKJP, źródło: „Seans”, kanał: książka)

\footnotetext{
5 „A mnie się nie też wydaje” — w przykładzie został zachowany oryginalny szyk z NKJP.
} 
Literatura przedmiotu odzwierciedla kontrowersje, co do statusu tego rodzaju wypowiedzeń. Kontynuację analiz zaczniemy od skonstatowania, że odróżnić można od siebie dwa przeciwstawne obozy w związku z interpretacją powyższych przykładów: zwolenników pierwszego obozu będziemy nazywać ,zwolennikami koniunkcji”, zwolenników drugiego ,zwolennikami alternatywy rozłącznej”.

Przechodzimy do scharakteryzowania stanowiska zwolenników koniunkcji. Jej zwolennicy (np. Lehrer 2015; Ciecierski 2013; Pritchard 2013) twierdzą, że wypowiedzi tego rodzaju są eliptyczne i należy je odpowiednio rozwinąć. Za ich pomocą wyraża się to, że danemu podmiotowi epistemicznemu nie tylko odpowiada stan mentalny A, ale też stan mentalny B. Przy takiej interpretacji nie mamy do czynienia z wypowiedziami korygującymi, ale z uzupetnieniami albo dopowiedzeniami. Uszczegółowione twierdzenie tego obozu może brzmieć następująco: kiedy ktoś mówi np.:

(25) Nie sadzę, że wyjechała, wiem to.

(26) On nie jest przekonany, że wyjechała. On to wie.

to wykonuje operację, która powoduje, że pewne wyrażenia nie pojawiają się na powierzchni wypowiedzianego zdania. Zdania bez opuszczonych wyrażeń wyglądają jak w przykładach (27)-(28):

(27) Nie tylko sądzę, że wyjechata, ale też to wiem.

(28) On nie tylko jest przekonany, że wyjechała. On też to wie.

Pritchard (2013: 5) podaje następujący argument na rzecz tego twierdzenia:

Czasami w wyraźny sposób kontrastujemy przekonania i wiedzę, tak jak wtedy, gdy mówimy rzeczy w rodzaju „nie wierzę w to, że on był niewinny, ja to wiem”, co może na pierwszy rzut oka sugerować, że wiedza nie wymaga przekonania. Jeśli jednak zastanowimy się nad tego rodzaju twierdzeniami, to okaże się jasne, że kontrast między przekonaniem a wiedzą jest tutaj użyty tylko po to, by podkreślić fakt, że nie tylko wierzymy w treść zdania dopełnieniowego, ale również wiemy, że jest ono prawdą. W ten sposób twierdzenia te wspierają stanowisko, że wiedza wymaga przekonania, a nie je podważają6.

Argument Pritcharda można streścić następująco: jeśli dobrze przyjrzymy się tego typu wypowiedzeniom, to uświadomimy sobie, że mówią one o koniunkcji wiedzy, że $p$ i przekonania (wiary), że $p$.

Nie możemy przyjąć tego argumentu, ponieważ w żaden sposób nie potwierdza on tezy, którą ma wspierać. Argumentem o takiej samej wartości jest twierdzenie, że jeśli dobrze przyjrzymy się tego typu wypowiedzeniom, to uświadomimy sobie, że nie mówią one o koniunkcji wiedzy, tylko wyrażają to, że ktoś nie znajduje się w stanie $A$, tylko w stanie $B$. Lehrer (2015: 26) pisze z kolei tak:

6 Tłum. własne. 
[...] Jest sensowne i nawet poprawne powiedzieć „Nie jestem o tym przekonany, wiem to” lub „On w to nie wierzy, on to wie". Powód, dla którego ma sens mówienie o tych rzeczach, można znaleźć w badaniach bardziej z zakresu retoryki niż logiki. Jest sensowne powiedzieć „Nie jestem o tym przekonany, wiem to" nie dlatego, że jest logiczną niekonsekwencją powiedzieć, że wierzy się w to, co się wie, ale raczej dlatego, że jest to emfatyczny sposób powiedzenia „Nie tylko jestem o tym przekonany: wiem to". Jednakże powiedzenie tego ostatniego jest całkowicie zgodne z tym, że osoba, o której stanach się mówi, nie tylko wierzy w to, o czym mówi, że wie. Podobne uwagi dotyczą zwrotu „Ona w to nie wierzy, ona to wie". Całkowita analogia do tych wypadków to taka, w której sensowne jest powiedzenie „To nie jest dom, to jest dwór”, a powodem, dla którego ma to sens, nie jest logiczna niekonsekwencja powiedzenia, że dom do dwór, ale raczej, że jest to emfatyczny sposób powiedzenia, że „To nie tylko dom, to jest dwór”. Faktycznie rzecz biorąc, to, że coś jest dworem, pociąga za sobą to, że jest to dom. Jeśli zrozumiemy retoryczny aspekt wypowiedzi emfatycznej, logika pozostaje nienaruszona ${ }^{7}$.

Fragment ten można sparafrazować w następujący sposób - (I) tego rodzaju wypowiedzenia są pewnego rodzaju retorycznym zabiegiem. Jest to stanowczy sposób powiedzenia, że dana osoba nie tylko jest w jednym stanie mentalnym, ale też w innym, mocniejszym, (II) oprócz tego możemy skonstruować argument z analogii na rzecz tego twierdzenia. Wypowiedzenia takie jak:

(29) To nie mieszkanie, to pałac.

należy rozumieć tak:

(30) To nie tylko mieszkanie, to pałac.

dlatego też wypowiedzenia takie jak:

(31) Ona nie jest o tym przekonana, ona to wie.

należy rozumieć następująco:

(32) Ona nie tylko jest o tym przekonana, ona to wie.

Należy tak właśnie postępować, ponieważ (29) jest analogiczne do (31).

Argument (I) Lehrera jest bardzo podobny do argumentu Pritcharda, dlatego nie będziemy się nim zajmować. Argument (II), będący argumentem z analogii, wymaga już stosownego komentarza. Argumentację autora można zrekonstruować w następujący sposób: wypowiedź o formie:

(33) To nie jest $x$ [rzeczownik], to jest $y$ [rzeczownik]. [gdzie: $y$ jest hiponimem $x$-a] należy odczytywać w następujący sposób:

(34) To nie tylko $x$ [rzeczownik], to jest $y$ [rzeczownik]. [gdzie: $y$ jest hiponimem $x$-a]

$Z$ racji, że (34) jest odczytaniem (33), to wypowiedź o formie:

(35) Ona nie jest $x$-ująca [czasownik epistemiczny], ona jest y-ujaca [czasownik epistemiczny].

7 Tłum. własne. 
powinniśmy odczytywać w następujący sposób:

(36) Ona jest nie tylko $x$-ujaca [czasownik epistemiczny], ona jest y-ujaca [czasownik epistemiczny].

Czasownik podstawiony za $y$-owanie musi być zatem hiponimem czasownika podstawionego za $x$-owanie.

Powyższego argumentu nie możemy przyjąć, ponieważ brak jest uzasadnienia dla twierdzenia, że poprawnym odczytaniem (33) jest (34). Brakuje wyjaśnienia, dlaczego na zdaniach typu (33) postuluje się pewnego rodzaju operację, zamiast odczytania literalnego. Ponadto brak uzasadnia dla twierdzenia, że jeśli jakaś para rzeczowników jest hipo-hiperonimiczna, to jakaś para czasowników też musi być hipo-hiperonimiczna. Argument ten mógłby mieć sens, gdyby wybrane rzeczowniki były w sposób istotny semantycznie powiązane z wybranymi czasownikami.

Z kolei argumentacja Ciecierskiego (2013: 175-176) przedstawia się następująco: (III) wypowiedzenia w rodzaju (31) są „wariantem powiedzenia, że «A nie tylko sądzi, że p, on wie, że p»»". Jest to narzucająca się naturalna interpretacja; (IV) Wypowiedzi tego rodzaju są analogiczne do wypowiedzeń obecnych w następującym dialogu:

(37) (a) - Miluś jest ptakiem.

(b) - Miluś nie jest ptakiem. On jest KONDOREM.

Wypowiedź (37b) powinna mieć następującą interpretację:

(38) Miluś nie jest jedynie ptakiem. On jest kondorem.

(37b) jest analogiczne do (31) dlatego jest to pozytywny argument za tym, by (17) traktować jako powiedzenie, że ktoś doświadcza dwóch stanów mentalnych (wiedzy i przekonania) jednocześnie.

Drugi argument Ciecierskiego jest identyczny z argumentem Lehrera $\mathrm{z}$ tym wyjątkiem, że Ciecierski zwraca jeszcze uwagę na to, że rzeczownik po prawej stronie może być wypowiedziany z emfazą oraz osadza przykład w dialogu. Argument pierwszy tego autora jest o wiele ciekawszy. Twierdzenie, że odczytanie, za którym się opowiada, jest „narzucającą się naturalną interpretacją”, można skontrować jedynie poprzez powiedzenie, że są badacze, którzy nie podzielają tej intuicji lub mają intuicje przeciwne. Byłyby to wtedy argumenty o równorzędnej wartości.

Dla uwypuklenia słabości wyżej omówionych argumentów poniżej przedstawiamy lustrzany argument Lehrera i Ciecierskiego. Wypowiedzenia w rodzaju:

(39) To ciężarówka, nie pickup.

(40) On tam nie poleciat, on tam pojechat.

nie mogą podlegać odczytaniu:

(41) To ciężarówka, nie tylko pickup. 
(42) On nie tylko tam poleciat, on tam pojechat.

Dlatego też wypowiedzenia typu: (31) Ona nie jest o tym przekonana, ona to wie. nie mogą podlegać odczytaniu takiemu jak: (43) Ona nie tylko jest o tym przekonana, ona to wie.

Argument ten jest równoważny argumentowi Lehrera i Ciecierskiego. Jeśli więc zwolennik koniunkcji dojdzie do wniosku, że nie ma powodu uzasadniać, dlaczego jest tak, że jeśli jedna para rzeczowników w danej konstrukcji syntaktycznej jest hipo-hiperonimiczna, to jakaś para czasowników, niezwiązana w żaden sposób semantycznie z tymi rzeczownikami, w analogicznym schemacie syntaktycznym też ma być hipo-hiperonimiczna, to musi poradzić sobie z lustrzanym kontragumentem, który prowadzi do przeciwnego wniosku niż ten, za którym się opowiada.

Przeciwko powyższym twierdzeniom można wysunąć inny zarzut: brakuje wyjaśnienia, dlaczego w ogóle powinno się postulować potrzebę jakiejś ,interpretacji” czy „odczytania” analizowanego typu wypowiedzi. Postulowana interpretacja może być zbudowana z pewnej klasy wyrażeń językowych. Wymieniani autorzy posługują się np. spójnikiem skorelowanym nie tylko..., lecz_ ${ }_{-}^{8}$ (z możliwym opuszczeniem jego prawej części). Poniżej przykłady użycia tego spójnika:

(44) Współczesne maszyny nie tylko musza być poprawnie skonstruowane i starannie wykonane, ale także musza spetniać wymagania ergonomiczne $i$ wynikajace z zasad ochrony środowiska. (Korpus Języka Polskiego PWN (KJPPWN), źródło: „Koparki. Teoria i projektowanie”, typ: książka)

(45) Jeśli za Kretą spadnie na nas wiatr północny, już nie tylko ładunek, ale i ludzie moga poginać... (KJPPWN, źródło: „Święty miecz”, typ: książka)

Nasuwa się zasadne pytanie, na które zwolennik koniunkcji powinien odpowiedzieć - dlaczego nadawca wypowiedzi od razu nie wybierze „rozwiniętej formy” w postaci np. nie tylko $x$, lecz $y$, tylko stosuje inną konstrukcję, która ma wyrażać to, co tamta wyraża literalnie?

Innym zarzutem, który można postawić tego typu twierdzeniom, jest konstatacja, że jest to stanowisko wewnętrznie sprzeczne. Argumentem na rzecz takiej tezy może być następujące rozumowanie: Formuła zdaniowa

(46) Nie tylko sądzę, że p, ale i wiem, że p.

implikuje ${ }^{9}$

(47) Wiem, że p.

(48) Nie wiem, czy p.

8 To jeden $\mathrm{z}$ jego wariantów.

9 Innymi słowy pociaga semantycznie (mamy na myśli wynikanie semantyczne będące odpowiednikiem wynikania logicznego na formułach logicznych). 
Ciężar argumentacyjny spoczywa w powyższym przykładzie na uzasadnieniu ,(47) $\rightarrow$ (49)" bądź “,sądze, że p" $\rightarrow$ „Nie wiem, czy p"”. W naszym przekonaniu nie istnieją jednak obecnie argumenty, które w sposób konkluzywny uzasadniałyby istnienie takiego systemowego wynikania. Możliwe jest jednak stworzenie modelu semantycznego dla języka naturalnego, w którym takie wynikanie byłoby traktowane właśnie jako wynikanie systemowe, a nie np. jako implikatura skalarna. Zarzut sprzeczności omawianego stanowiska można więc zasadnie postawić tylko na gruncie konkretnego modelu. Argumenty na rzecz twierdzenia, że nie mamy do czynienia przy tego typu wypowiedzeniach z implikaturą skalarną, można znaleźć w artykule A. Bogusławskiego, poświęconym w szczególności wywodom Ciecierskiego na omawiany przez nas temat (Bogusławski 2016).

Podobny w istocie kontrargument opiera się na rozróżnieniu na czasowniki faktywne i niefaktywne. Czasownik wiedzieć, że_należy do czasowników faktywnych, natomiast np. czasowniki sądzić, że_, być przekonanym, że_uważać, że , wierzyć, $\dot{z} e_{-}$są niefaktywne (Kiparsky, Kiparsky 1971). W świetle tego podziału wypowiedzenie typu

(49) Ona jest nie $x$-ujaca [czasownik niefaktywny], że p, lecz także jest y-ujaca, że $p$ [czasownik faktywny].

byłoby kontrinformatywne, ponieważ można z niego systemowo wyprowadzić następujące implikacje:

(51) $p$ lub $\sim p$

Wynikanie formuły (51) ufundowane jest na własności faktywności czasownika po prawej (np. wiedzieć, że_), a wynikanie formuły (52) ufundowane jest na mocy niefaktywności czasownika po lewej (np. sądzić, że_).

Przechodzimy do omówienia stanowiska przeciwnego. Jego zwolennicy (np. Danielewiczowa 2002, Bogusławski 2016) twierdzą, że wypowiedzi tego rodzaju należy rozumieć dosłownie — nie są to konstrukcje eliptyczne. Nadawca wypowiedzi informuje, że nie charakteryzuje go stan mentalny A, lecz inny stan mentalny B i że stany te się wykluczają, czyli nie zachodzi pomiędzy nimi relacja hipo-hiperonimii. Taka interpretacja jest spójna z będącym punktem wyjścia tego artykułu założeniem, że przedmiotem analizy w nim zawartym są wypowiedzi korygujące. W ten sposób nazywa je też Bogusławski (2016). Na rzez takiej interpretacji można podać następujące argumenty pozytywne.

Po pierwsze, twierdzimy, że jest to naturalnie narzucająca się interpretacja. Jak zostało wyżej powiedziane, przeciwny obóz może powiedzieć to samo, dlatego argumenty $\mathrm{z}$ intuicji językowej się równoważą.

Po drugie, charakteryzuje się ona większą prostotą w stosunku do omawianej interpretacji konkurencyjnej — nie postuluje dodatkowych operacji na zdaniu, by móc przedstawić jego znaczenie. 
Po trzecie, odczytanie tego rodzaju wypowiedzi jako wypowiedzi korygujących i zarazem literalnych jest spójne z podziałem czasowników epistemicznych ze względu na własność faktywności.

Można jednak próbować wytoczyć argumenty przeciwko takiej interpretacji. Poniżej przedstawiamy dwa możliwe argumenty.

Po pierwsze, trójskładnikowa definicja wiedzy przypisywana Platonowi (tzw. Justified True Belief (JTB)) była w filozofii powszechnie uznawana za adekwatną aż do połowy XX w., do czasu tekstu Gettiera o znaczącym tytule „Is justified true belief knowledge?" (Gettier 1963). Jednak to nie warunek przekonaniowy był w nim przedmiotem kontrowersji, tylko warunek uzasadnienia. Także w literaturze po Gettierze, krytykującej definicje Platona, warunek przekonaniowy raczej nie podlegał krytyce.

Po drugie, skoro są to stany rozłączne, to jeden wyklucza drugi w takim samym stopniu jak drugi wyklucza pierwszy i kolejność nie ma znaczenia. Skoro więc za poprawną bez dopowiedzenia eliptycznego uznajemy wypowiedź „Nie jestem przekonany, ja to wiem”, to także za poprawną powinniśmy uznać wypowiedź „Wiem, ale nie jestem przekonany".

Argumenty te łatwo jednak obalić. Słabość pierwszego polega na tym, że definicja JTB nie znajduje potwierdzenia $\mathrm{w}$ analizie lingwistycznej, szeroko powołują się na nią przede wszystkim filozofowie. Argument ten możemy traktować jako kolejny argument $\mathrm{z}$ autorytetu i zarazem argument $\mathrm{z}$ (pewnej) większości. Twierdzenie, że istnienie wypowiedzi korygujących, w których czasownik wiedzieć, że_jest składnikiem korygującym, w sposób jednoznaczny potwierdza, że nie można jednocześnie wiedzieć i sądzić, że $p$. Jest to punkt widzenia spójny z teoretycznym podziałem na czasowniki faktywne i niefaktywne. Jeśli wiedzieć, że_jest czasownikiem faktywnym, a np. być przekonanym, że_nie jest, to ten drugi nie może być komponentem znaczeniowym pierwszego.

Do powyższego argumentu można podejść jeszcze w inny sposób - JTB nie jest definicją wyrażenia języka naturalnego (np. polskiego czasownika wiedzieć, że_), tylko jest to definicja filozoficznego pojęcia wiedzy. Wtedy jednak powoływanie się na JTB w analizie wypowiedzi typu ,nie sądzę, że p, ja to wiem” traci sens.

Argument drugi jest fałszywy z tego względu, że w przykładzie „Wiem, ale nie jestem przekonany" nie uwzględnia się semantyki spójnika ale, który jest kontrastywny (np. Wajszczuk 1997). Wypowiedź korygująca, w której predykat wiedzieć, że_jest po lewej stronie, mogłaby wyglądać np. tak: „Ja to WIEM, a nie “jestem przekonany””. Co prawda kolejność czasowników w tego typie konstrukcji nie ma znaczenia, ale pamiętać trzeba przy tym, że to nie jedyne wyrażenia, z których składają się analizowane wypowiedzi. 


\section{Podsumowanie}

Powyższe analizy skłaniają nas do następujących wniosków.

Po pierwsze, konstrukcja zawarta w tytule tego tekstu należy do typu wypowiedzi korygujących. Jest to nie tylko przyjęte założenie na początku tekstu, ale i podparte argumentami w artykule twierdzenie.

Po drugie, zachodzenie relacji hipo-hiperonimii pomiędzy składnikiem korygowanym a korygującym wymusza inny akcent niż neutralny pod groźbą dewiacji. Przypuszczalnie musi być to akcent kontrastywny. Ustalenia w tym zakresie muszą jednak być potwierdzone przez badania empiryczne. Jest to wciąż otwarty, dalszy obszar badań.

Po trzecie, faktywność czasownika będącego składnikiem korygującym i niefaktywność czasownika będącego składnikiem korygowanym jest elementem semantycznym, z którego powodu wprowadzana jest korekta w wypowiedzi (swojej lub czyjejś). Najlepiej widać to na czasownikach epistemicznych, np. w wypowiedziach (1)-(3) i (17)-(24).

Po czwarte, jeśli klasyczna definicja wiedzy dotyczy pojęcia wiedzy z języka naturalnego, to jeden z jej warunków — warunek przekonaniowy — powoduje, że jest błędna. Wynika to z tego, że wyrażenie definiowane (wiedza, wiedzieć, że_) jest faktywne, a wyrażenie będące składnikiem jego definicji (być przekonanym/wierzyć/są$d z i c ́, \dot{z} e_{-}$itp.) jest niefaktywne.

Po piąte, istnienie wypowiedzi korygujących zbudowanych $\mathrm{z}$ czasownika wie-

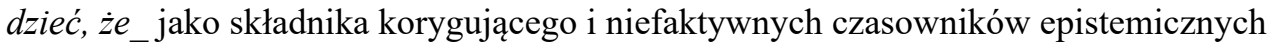
jako składnika korygowanego w sposób jednoznaczny falsyfikuje klasyczną definicję wiedzy, jeżeli przyjmie się, że dotyczy ona pojęcia z języka naturalnego (nie jest terminem specjalistycznym albo pojęciem filozoficznym).

Powyższe dwa wnioski niosą za sobą istotne konsekwencje dla prac z zakresu epistemologii. Wszystkie koncepcje filozoficzne, które w swoich założeniach przyjmują warunek przekonaniowy w klasycznej definicji oraz jednocześnie traktują ją jako definicję dotyczącą pojęcia z języka naturalnego, opierają się na błędnym założeniu. Zagadnienie to omawiamy szczegółowo w: Ziembicki, w przygotowaniu. 


\section{Bibliografia}

\section{Korpusy}

Narodowy Korpus Języka Polskiego: http://nkjp.pl/

Korpus Języka Polskiego PWN: http://sjp.pwn.pl/korpus

\section{Literatura}

Bogusławski A., 2016, Kolejna glosa do rozważań wokół pojęcia wiedzy i jej stosunku do niealetycznych stanów mentalnych, Linguistica Copernicana 13, s. 67-86.

Ciecierski T., 2013, Nastawienia sądzeniowe. Wykłady z filozofii psychologii, Warszawa.

Danielewiczowa M., 2002, Wiedza i niewiedza. Studium polskich czasowników epistemicznych, Warszawa.

Gettier E., 1963, Is justified true belief knowledge?, Analysis 23.6, s. 121-123.

Hazlett A., 2012, Factive Presupposition and the Truth Condition on Knowledge, Acta Analytica 27, nr 4, s. $461-478$.

Kiparsky P., Kiparsky C., 1971, Fact, [in:] Semantics: An interdisciplinary reader in philosophy, linguistics and psychology, ed. by D.D. Steinberg, L.A. Jakobovits, s. 345-369.

Lehrer K., 2015, Theory of knowledge, Colorado.

Ożóg K., 1990, Leksykon metatekstowy współczesnej polszczyzny mówionej: wybrane zagadnienia, Kraków.

Pęzik P., 2012, Wyszukiwarka PELCRA dla danych NKJP, Narodowy Korpus Języka Polskiego, red. Przepiórkowski A., Bańko M., Górski R., Lewandowska-Tomaszczyk B., Wydawnictwo PWN.

Pritchard D., 2013, What is this thing called knowledge?, London-New York.

Walusiak E., 1999, Hierarchizacja treści i nawiązanie wewnątrztekstowe: wykładniki leksykalne, Warszawa.

Wajszczuk J., 1997, System znaczeń w obszarze spójników polskich: wprowadzenie do opisu, Warszawa.

Żabowska M., 2008, Leksykalne sygnały korekty wypowiedzi, [w:] Studia o języku i stylu artystycznym, t. IV: Stylistyka a leksykologia. Związki, zależności, metody, red. K. Maćkowiak, C. Piątkowski, Zielona Góra, s. 131-141.

\section{SUMMARY}

Controversies around the interpretation of utterances as Nie sqdzę, że p, ja to wiem (I don't believe that p, I know it)

Keywords: semantics, factivity, knowledge, epistemic verbs, corrective sentences.

Słowa kluczowe: semantyka, faktywność, wiedza, czasowniki epistemiczne, zdania korygujące.

The subject of the paper are such types of utterances as Nie sadzę, ze p, ja to wiem (I don't believe that $p$, I know it). In particular, interpretive controversies of this kind of utterances are discussed. The applied research method consists in a comparative analysis of the collected language material. Moreover, the presented extensive empirical material confirms the thesis that such utterances are indeed corrective. The conclusions from the analyses support the thesis that the classical definition of knowledge (of justified true belief) is internally contradictory due to the fact that verb wiedzieć, że_(know that_) is defined by a non-factive verb być przekonanym, że_(be convinced that_). 